\title{
CMIP5 Projections of Two Types of EI Niño and Their Related Tropical Precipitation in the Twenty-First Century ${ }^{\mathscr{O}}$
}

\author{
KANG XU \\ State Key Laboratory of Tropical Oceanography, South China Sea Institute of Oceanology, Chinese Academy of \\ Sciences, Guangzhou, and Earth System Science Programme, The Chinese University of Hong Kong, \\ Hong Kong, China \\ CHI-YUNG TAM \\ Earth System Science Programme, The Chinese University of Hong Kong, Hong Kong, China \\ CONGWEN ZHU AND BOQI LIU \\ Institute of Climate Systems, Chinese Academy of Meteorological Sciences, Beijing, China \\ WEIQIANG WANG \\ State Key Laboratory of Tropical Oceanography, South China Sea Institute of Oceanology, Chinese Academy of \\ Sciences, Guangzhou, China
}

(Manuscript received 1 June 2016, in final form 2 September 2016)

\begin{abstract}
Future projections of the eastern-Pacific (EP) and central-Pacific (CP) types of El Niño in the twenty-first century, as well as their associated tropical circulation and precipitation variability, are investigated using historical runs and representative concentration pathway 8.5 (RCP8.5) simulations from 31 coupled models in phase 5 of the Coupled Model Intercomparison Project (CMIP5). As inferred from CMIP5 models that best capture both El Niño flavors, EP El Niño sea surface temperature (SST) variability will become weaker in the future climate, while no robust change of $\mathrm{CP}$ El Niño SST is found. Models also reach no consensus on the future change of relative frequency from $\mathrm{CP}$ to EP El Niño. However, there are robust changes in the tropical overturning circulation and precipitation associated with both types of El Niño. Under a warmer climate, magnitudes of precipitation anomalies during EP El Niño are projected to increase, presenting significant enhancement of the dry (wet) signal over the western (central-eastern) Pacific. This is consistent with an accelerated hydrological cycle in the deep tropics; hence, a "wet get wetter" picture appears under global warming, accompanied by a weakened anomalous Walker circulation. For CP El Niño, drier-than-normal conditions will be intensified over the tropical central-eastern Pacific in the future climate, with stronger anomalous sinking related to the strengthened North Pacific local Hadley cell. These results suggest that, besides the enhanced basic-state hydrological cycle over the tropics, other elements, such as the anomalous overturning circulation, might also play a role in determining the ENSO precipitation response to a warmer background climate.
\end{abstract}

\section{Introduction}

El Niño-Southern Oscillation (ENSO) is the most pronounced interannual climate phenomenon resulting from ocean-atmosphere interaction in the tropical

Supplemental information related to this paper is available at the Journals Online website: http://dx.doi.org/10.1175/JCLI-D-16-0413.s1.

Corresponding author e-mail: Chi-Yung Tam,francis.tam@cuhk. edu.hk
Pacific (McPhaden et al. 2006). Its environmental and socioeconomic impacts, however, can extend far beyond the tropics through the atmospheric bridge mechanism (e.g., Lau and Nath 1996; Wang et al. 2000; Alexander et al. 2002; Wu et al. 2003). Because of the distinct geographical patterns of the recurrent sea surface temperature (SST) anomalies, El Niño events can be classified into two types: one is the so-called conventional eastern Pacific (EP) El Niño, with maximum warming localized in the eastern equatorial Pacific, and the other is referred to as the central Pacific (CP) El Niño, with 
strongest positive SST anomalies found in the central equatorial Pacific (Larkin and Harrison 2005; Ashok et al. 2007; Yu and Kao 2007; Kug et al. 2009; Wang and Wang 2013). The time evolution of the EP El Niño cycle can be mostly explained by classic ENSO theories, but there are still debates about the initiation mechanism of CP El Niño (e.g., Ashok et al. 2007; Kug et al. 2009; Yu et al. 2010; Yu and Kim 2011; Xiang et al. 2013; Su et al. 2014). A number of studies have suggested these two types of El Niño have rather distinct atmospheric teleconnections and hence regional climate impacts in different seasons (e.g., Weng et al. 2007; Ashok et al. 2009, 2014; Yeh et al. 2009, 2015; Cai and Cowan 2009; Di Lorenzo et al. 2010; Chen and Tam 2010; Feng et al. 2010; Zhang et al. 2011, 2014, 2015; Feng and Li 2011, 2013; Wu et al. 2012; Yu et al. 2012, 2015; Xu et al. 2013; Banholzer and Donner 2014). Recently much attention has been paid to the occurrence frequencies of the two ENSO flavors. For instance, Yeh et al. (2009) reported that climate change due to anthropogenic forcing can increase CP El Niño events but has little influence on EP El Niño. However, more recent studies suggested that great uncertainty still exists on how the relative frequency of the two types of El Niño might change in the future climate (Yeh et al. 2014). Power et al. (2013) stressed that no consensus has been reached on such changes among most models participating in phase 5 of the Coupled Model Intercomparison Project (CMIP5; see Taylor et al. 2012). Taschetto et al. (2014) pointed out that, among the 34 CMIP5 models examined, there are no consistent changes in either the location and magnitude of the strongest SST anomalies or the temporal characteristics of the two types of El Niño under a warmer climate.

Evidence suggested that the global mean precipitation is projected to increase, but at a smaller rate compared to that of atmospheric water vapor under global warming (Held and Soden 2006). The consequence is that an accelerated hydrological cycle is concomitant with a weakened tropical circulation in a warmer background climate (e.g., Held and Soden 2006; Watanabe et al. 2014). This is referred to as the "wet get wetter" picture, in which precipitation tends to increase over regions with the wet mean conditions. The other (not incompatible) mechanism for the influences of global warming on regional precipitation is called the "warmer get wetter" mechanism (Xie et al. 2010), which emphasizes the effect of changes in SST patterns on modulating tropical precipitation. The more recent study of Huang et al. (2013) proposed that changes in the seasonal cycle of the tropical precipitation under global warming could be interpreted as a combination of wetget-wetter and warmer-get-wetter patterns over the tropical oceans.
Tropical precipitation variability plays a crucial role in ENSO dynamics and is a major driver of ENSO teleconnections (e.g., McPhaden et al. 2006; Kug et al. 2010). The relationships between ENSO and tropical precipitation in the future climate have been recently addressed by a number of studies. Kug et al. (2010) indicated that ENSO teleconnections to the Northern Hemisphere will shift eastward under global warming, owing to an eastward shift of ENSO-related anomalous convection near the equator. Power et al. (2013) demonstrated that there are robust changes in the projected El Niño-driven precipitation, presenting intensified drying and wetting in the western Pacific and east of the date line, respectively. Ham et al. (2015) emphasized that changes in the climatological state due to global warming are essential for the independency between EP and CP El Niño events. Cai et al. $(2014,2015)$ found a large increase in extreme El Niño events, which facilitates extreme rainfall in the eastern equatorial Pacific and equatorward swings of the Pacific convergence zones in future climate projections.

Previous studies have examined the projected changes of EP El Niño events and their related teleconnection under global warming, but little literature has paid attention to future changes in CP El Niño and especially its associated tropical precipitation variability. The aim of this study is to assess the capability of CMIP5 models in simulating the two types of El Niño and to examine the model-projected changes in the El Niño-driven precipitation anomalies. In addition, the relationships between changes of atmospheric circulation related to the two El Niño flavors and the background circulation variation due to a warmer climate will be probed. The remainder of the paper is organized as follows. Section 2 introduces the datasets and methods applied. Evaluation of two types of El Niño in the CMIP5 model simulations, as well as their future projected characteristics, is provided in section 3. Section 4 examines changes of tropical precipitation anomalies associated with EP and CP El Niño and their close connection with the mean atmospheric circulation changes under a warmer background climate. A discussion and summary can be found in section 5 .

\section{Datasets and methodology}

Model experiments from 31 state-of-the-art CMIP5 coupled global climate models were utilized in this study. Table 1 shows information, such as the model holders and horizontal and vertical resolutions (see also http://www-pcmdi.llnl.gov). For each model, output from historical runs and future climate projections based on the representative concentration pathway 8.5 (RCP8.5) 
were selected for analyses. Both natural and anthropogenic forcing in the twentieth century were prescribed in the historical simulations, and, in the RCP8.5 experiments, rising radiative forcing leading to $8.5 \mathrm{~W} \mathrm{~m}^{-2}$ by 2100 (equivalent to $1370 \mathrm{ppm}$ of $\mathrm{CO}_{2}$ ) representing a high emission scenario was imposed (van Vuuren et al. 2011). The projected future climate changes were extracted by the differences of model circulations between 1950-99 historical periods and 2050-99 under RCP8.5. We considered only one member of the ensemble integration from each model for both the historical runs and RCP8.5 experiments. All model output were first interpolated onto the same spatial grid of $1^{\circ} \times 1^{\circ}$ horizontal resolution before analysis. In addition, to assess the fidelity of the simulated ENSO variability, model SST data were compared to their observational counterpart at the same horizontal resolution from the Hadley Centre Sea Ice and Sea Surface Temperature (HadISST, version 1.1) analysis for the period of 1950-99 (Rayner et al. 2003). Observed precipitation data were taken from the monthly analysis of the Global Precipitation Climatology Project (GPCP, version 2.2; Adler et al. 2003), covering the period of 1979-2010 with a horizontal resolution of $2.5^{\circ} \times 2.5^{\circ}$. Monthly mean variables from models and observations were smoothed by taking 3-month running averages to suppress subseasonal variability. Finally, the climatological mean for the historical (RCP8.5) run is computed by taking the average from 1950 to 1999 (from 2050 to 2099), and anomalous conditions are defined as the deviation from the climatological mean of a particular variable.

In this study, the multimodel ensemble (MME) mean is computed as the simple average of results from all selected models; by considering the MME mean, errors related to intermodel variability can be reduced (Gupta et al. 2013). Here we also use "intermodel consistency" to evaluate the robustness of climate signals from the MME projections. Specifically, for a certain scalar field (e.g., SST), the intermodel consistency is defined as the fraction of models that project the same sign change as that given by the MME average. For a vector quantity, it is defined as the maximum value of the consistency of either its zonal or meridional component. For the intermodel consistency to attain a 5\% level of significance, more than $70 \%$ of models need to produce the same change of sign for a particular variable, based on a binomial distribution (Power et al. 2012).

\section{Simulations of two types of EI Niño and their projected changes}

\section{a. Evaluation of El Niño-related SST variability in CMIP5 models}

To study the interannual SST variability over the tropical Pacific, both the observed and model-generated
SST fields were first bandpass filtered to retain variations with periods less than 9 years. We then performed the empirical orthogonal function (EOF) analysis on the filtered monthly mean SST over the domain of $30^{\circ} \mathrm{S}-$ $30^{\circ} \mathrm{N}, 120^{\circ} \mathrm{E}-80^{\circ} \mathrm{W}$ to distinguish the two types of $\mathrm{El}$ Niño events. Figure 1 shows the first and second leading EOF patterns in observations for the 1950-99 period, which are computed by regressing the SST anomalies onto the corresponding principal components. The first EOF (EOF1), which explains $51.6 \%$ of the domainintegrated SST variability on the interannual time scale, captures the EP El Niño SST pattern, with anomalous warming in the central-eastern equatorial Pacific and cooling in the western tropical Pacific (Fig. 1a). The second EOF (EOF2) with an explained variance of $8.6 \%$ is characterized by warmer-than-normal SST in the central equatorial Pacific and cold anomalies in the eastern tropical Pacific. Note that a local maximum in the SST variance also extends into the subtropical latitudes, especially in the Northern Hemisphere; this suggests that SST anomalies in the northeastern Pacific might also play a role on the development of $\mathrm{CP} \mathrm{El}$ Niño. Meanwhile, anomalously cold SST can be discerned over the far-western equatorial Pacific (Fig. 1b). Overall, the aforementioned SST pattern associated with EOF2 is consistent with that for El Niño Modoki (Ashok et al. 2007) or CP El Niño (Yu and Kao 2007).

We now apply the same EOF analysis on the interannual SST anomalies in the historical runs of 31 CMIP5 models. Inspections of the resulting EOFs revealed that EOF1 in all runs can describe the EP El Niño SST pattern as in observations (see Fig. S1 in the supplementary material), indicating that climate models are able to capture SST variability associated with EP El Niño. However, it was found that the observed CP El Niño SST pattern is described by the EOF2 mode in some models, but by the third leading EOF (EOF3) in other ones (see Fig. S2 in the supplementary material). Figure 2a presents the spatial correlation coefficients of the observed EOF2 with the simulated EOF2 and EOF3 in the 31 CMIP5 models. Results clearly show that none of the models gives spatial correlation higher than 0.8 , except the MPI-ESM-MR, suggesting that not all CMIP5 models can faithfully reproduce the observed CP El Niño. Thus, based on SST simulations from each CMIP5 model, whichever simulated EOF among the first three leading ones that bears the greatest resemblance with observed EOF2 is chosen to represent the CP El Niño mode for that particular model. Accordingly, we found that $\mathrm{CP} \mathrm{El}$ Niño simulated by nine models [viz., ACCESS1.0, BCC_CSM1.1, BCC_CSM1.1(m), CCSM4, CESM1(BGC), CESM1(CAM5), CMCC-CMS, HadGEM2-ES, and IPSL-CM5A-LR] are represented 
TABLE 1. Description of the 31 CMIP5 coupled models analyzed in this study. The 17 models capable of simulating both EP and CP El Niño are marked in boldface font. See text for details. (Expansions of acronyms are available at http://www.ametsoc.org/ PubsAcronymList.)

\begin{tabular}{|c|c|c|c|c|}
\hline No. & Model & Modeling group (or center) & $\begin{array}{c}\text { AGCM resolution } \\
(\text { lon } \times \text { lat grid points, } \\
\text { vertical levels })\end{array}$ & $\begin{array}{c}\text { OGCM resolution } \\
(\text { lon } \times \text { lat grid points, } \\
\text { vertical levels })\end{array}$ \\
\hline 1 & ACCESS1.0 & $\begin{array}{l}\text { Commonwealth Scientific and } \\
\text { Industrial Research Organisation } \\
\text { (CSIRO) and Bureau of } \\
\text { Meteorology (BoM), Australia }\end{array}$ & $192 \times 144$, L38 & $360 \times 300$, L50 \\
\hline 2 & ACCESS1.3 & CSIRO and BOM, Australia & $192 \times 144, \mathrm{~L} 38$ & $360 \times 300, \mathrm{~L} 50$ \\
\hline 3 & BCC_CSM1.1 & $\begin{array}{l}\text { Beijing Climate Center (BCC), China } \\
\text { Meteorological Administration (CMA), } \\
\text { China }\end{array}$ & $128 \times 64, \mathrm{~L} 26$ & $360 \times 232, \mathrm{~L} 40$ \\
\hline 4 & BCC_CSM1.1(m) & BCC, CMA, China & $320 \times 160, \mathrm{~L} 26$ & $360 \times 232, \mathrm{~L} 40$ \\
\hline 5 & CanESM2 & $\begin{array}{l}\text { Canadian Centre for Climate } \\
\text { Modelling and Analysis (CCCma), } \\
\text { Canada }\end{array}$ & $128 \times 64, \mathrm{~L} 35$ & $256 \times 192, \mathrm{~L} 40$ \\
\hline 6 & CCSM4 & $\begin{array}{l}\text { National Center for Atmospheric } \\
\text { Research (NCAR), United States }\end{array}$ & $288 \times 192, \mathrm{~L} 26$ & $384 \times 320$, L60 \\
\hline 7 & CESM1(BGC) & NCAR, United States & $288 \times 192, \mathrm{~L} 26$ & $384 \times 320$, L60 \\
\hline 8 & CESM1(CAM5) & NCAR, United States & $288 \times 192, \mathrm{~L} 26$ & $384 \times 320$, L60 \\
\hline 9 & СМСС-CM & $\begin{array}{l}\text { Centro Euro-Mediterraneo per I } \\
\text { Cambiamenti Climatici (CMCC), Italy }\end{array}$ & $480 \times 240, \mathrm{~L} 31$ & $182 \times 149, \mathrm{~L} 31$ \\
\hline 10 & CMCC-CMS & CMCC, Italy & $192 \times 96$, L95 & $182 \times 149, \mathrm{~L} 31$ \\
\hline 11 & CNRM-CM5 & $\begin{array}{l}\text { Centre National de Recherches } \\
\text { Météorologiques/Centre Européen de } \\
\text { Recherche et Formation Avancée } \\
\text { en Calcul Scientifique, France }\end{array}$ & $256 \times 128, \mathrm{~L} 31$ & $362 \times 292, \mathrm{~L} 42$ \\
\hline 12 & CSIRO Mk3.6.0 & $\begin{array}{l}\text { CSIRO in collaboration with Queensland } \\
\text { Climate Change Centre of Excellence } \\
\text { (QCCCE), Australia }\end{array}$ & $192 \times 96, \mathrm{~L} 18$ & $192 \times 189, \mathrm{~L} 31$ \\
\hline 13 & FIO-ESM & $\begin{array}{l}\text { The First Institute of Oceanography, } \\
\text { State Oceanic Administration (SOA), } \\
\text { China }\end{array}$ & $128 \times 64, \mathrm{~L} 26$ & $320 \times 384, \mathrm{~L} 40$ \\
\hline 14 & GFDL CM3 & $\begin{array}{l}\text { NOAA/Geophysical Fluid Dynamics } \\
\text { Laboratory (GFDL), United States }\end{array}$ & $144 \times 90, \mathrm{~L} 48$ & $360 \times 200$, L50 \\
\hline 15 & GFDL-ESM2G & NOAA/GFDL, United States & $144 \times 90, \mathrm{~L} 24$ & $360 \times 210$, L63 \\
\hline 16 & GFDL-ESM2M & NOAA/GFDL, United States & $144 \times 90, \mathrm{~L} 24$ & $360 \times 200, \mathrm{~L} 50$ \\
\hline 17 & GISS-E2-H & $\begin{array}{l}\text { National Aeronautics and Space } \\
\text { Administration (NASA) Goddard } \\
\text { Institute for Space Studies (GISS), } \\
\text { United States }\end{array}$ & $144 \times 89, \mathrm{~L} 40$ & $144 \times 90, \mathrm{~L} 26$ \\
\hline 18 & GISS-E2-R & NASA GISS, United States & $144 \times 89, \mathrm{~L} 40$ & $144 \times 90, \mathrm{~L} 32$ \\
\hline 19 & HadGEM2-AO & $\begin{array}{l}\text { National Institute of Meteorological } \\
\text { Research/Korea Meteorological } \\
\text { Administration, South Korea }\end{array}$ & $192 \times 144$, L38 & $360 \times 216, \mathrm{~L} 40$ \\
\hline 20 & HadGEM2-CC & $\begin{array}{l}\text { Met Office Hadley Centre, United } \\
\text { Kingdom }\end{array}$ & $192 \times 144, \mathrm{~L} 38$ & $360 \times 216, \mathrm{~L} 40$ \\
\hline 21 & HadGEM2-ES & $\begin{array}{l}\text { Met Office Hadley Centre, United } \\
\text { Kingdom }\end{array}$ & $192 \times 144$, L38 & $360 \times 216, \mathrm{~L} 40$ \\
\hline 22 & INM-CM4.0 & $\begin{array}{l}\text { Institute for Numerical Mathematics } \\
\text { (INM), Russia }\end{array}$ & $180 \times 120, \mathrm{~L} 21$ & $360 \times 340, \mathrm{~L} 40$ \\
\hline 23 & IPSL-CM5A-LR & $\begin{array}{l}\text { L'Institut Pierre-Simon Laplace (IPSL), } \\
\text { France }\end{array}$ & $96 \times 96$, L39 & $182 \times 149, \mathrm{~L} 31$ \\
\hline 24 & IPSL-CM5A-MR & IPSL, France & $144 \times 143$, L39 & $182 \times 149$, L31 \\
\hline 25 & IPSL-CM5B-LR & IPSL, France & $96 \times 96$, L39 & $182 \times 149$, L31 \\
\hline
\end{tabular}


TABLE 1. (Continued)

\begin{tabular}{|c|c|c|c|c|}
\hline No. & Model & Modeling group (or center) & $\begin{array}{c}\text { AGCM resolution } \\
\text { (lon } \times \text { lat grid points, } \\
\text { vertical levels })\end{array}$ & $\begin{array}{c}\text { OGCM resolution } \\
\text { (lon } \times \text { lat grid points, } \\
\text { vertical levels })\end{array}$ \\
\hline 26 & MIROC5 & $\begin{array}{l}\text { Atmosphere and Ocean Research } \\
\text { Institute (The University of Tokyo), } \\
\text { National Institute for Environmental } \\
\text { Studies, and Japan Agency for } \\
\text { Marine-Earth Science and Technology, } \\
\text { Japan }\end{array}$ & $256 \times 128, \mathrm{~L} 40$ & $256 \times 224, \mathrm{~L} 50$ \\
\hline 27 & MPI-ESM-LR & $\begin{array}{l}\text { Max Planck Institute for Meteorology } \\
\text { (MPI-M), Germany }\end{array}$ & $192 \times 96, \mathrm{~L} 47$ & $256 \times 220, \mathrm{~L} 40$ \\
\hline 28 & MPI-ESM-MR & MPI-M, Germany & $192 \times 96, \mathrm{~L} 47$ & $802 \times 404, \mathrm{~L} 40$ \\
\hline 29 & MRI-CGCM3 & $\begin{array}{l}\text { Meteorological Research Institute (MRI), } \\
\text { Japan }\end{array}$ & $320 \times 160, \mathrm{~L} 48$ & $368 \times 360$, L51 \\
\hline 30 & NorESM1-M & $\begin{array}{l}\text { Norwegian Climate Centre (NCC), } \\
\text { Norway }\end{array}$ & $144 \times 96, \mathrm{~L} 26$ & $384 \times 320$, L53 \\
\hline 31 & NorESM1-ME & NCC, Norway & $144 \times 96, \mathrm{~L} 26$ & $384 \times 320$, L53 \\
\hline
\end{tabular}

by their EOF3; for the remaining 24 models, CP El Niño corresponds to EOF2 of the interannual SST variability. To summarize these results, the spatial correlation values between the observed and model-simulated EP and CP El Niño SST are provided in Fig. 2b. For EP El Niño, all CMIP5 models give spatial correlation larger than 0.8 (with the exception of CSIRO Mk3.6.0), whereas, for $\mathrm{CP} \mathrm{El}$ Niño, the spatial correlation varies from 0.22 (BCC_CSM1.1) to 0.85 (MPI-ESM-MR). Furthermore, the MME mean of the spatial correlation for EP El Niño is +0.89 (with an intermodel spread of 0.06 , defined as one standard deviation of model correlation values), which is greater than its CP El Niño counterpart of +0.56 (with a spread of 0.13 ). Thus, the CMIP5 models perform better in simulating the EP than the CP El Niño, and we apply the value of $+0.85(+0.56)$ as a threshold to determine whether the models are capable of simulating EP (CP) El Niño. Accordingly, 17 out of the total 31 CMIP5 models (see models marked by boldface font in Table 1) can realistically reproduce both $\mathrm{EP}$ and $\mathrm{CP} \mathrm{El}$ Niño flavors in their historical runs
(Fig. 2b). To summarize, CMIP5 models are more capable in reproducing the observed EP El Niño but less so for CP El Niño. Our result is consistent with a previous study based on preindustrial control runs from the same CMIP5 models (Xu et al. 2014).

The MME mean of SST anomalies for two types of El Niño based on the 17 selected models are presented in Fig. 3. The MME average of EP El Niño SST anomalies greatly resembles observations with pattern correlation of 0.95 (Fig. 3a). The historically simulated CP El Niño SST pattern is also very similar to its observational counterpart, exhibiting a correlation coefficient of 0.84 between them (Fig. 3b). In the remaining part of this study, we will use these 17 models to infer the projected future changes of two El Niño flavors and their related tropical precipitation under global warming.

\section{b. Projected changes of EP and CP El Niño characteristics}

After assessing the models' ability in reproducing El Niño and its diversity, we now examine how climate
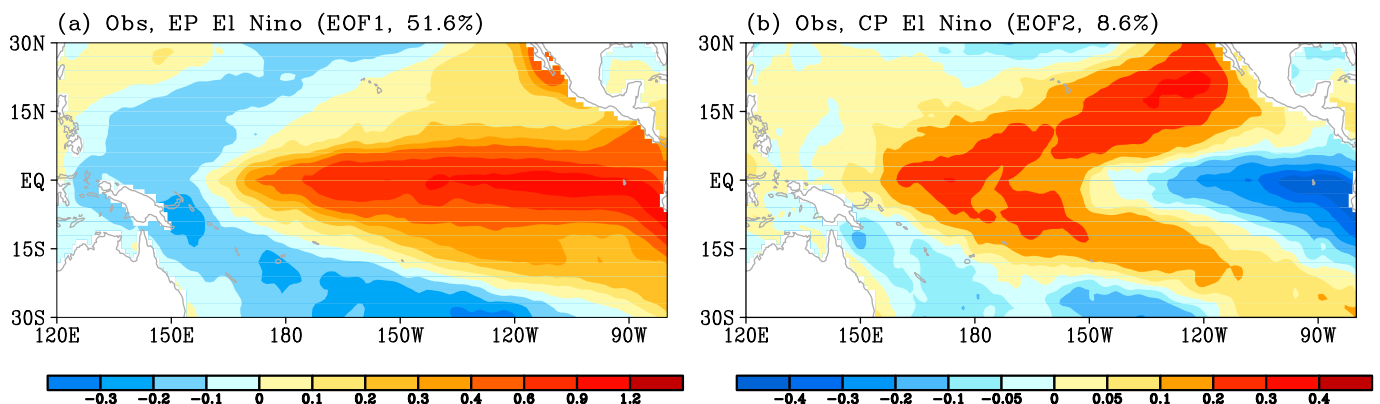

FIG. 1. The first and second leading EOF modes of the tropical Pacific SST anomalies corresponding to (a) EP and (b) CP El Niño in observations for the 1950-99 period. Percentage of variance explained by each EOF mode is shown in parentheses at the top of each panel. SST maps (K) corresponding to EP and CP El Niño are computed by regressing SST anomalies onto the first and second principal components, respectively. 

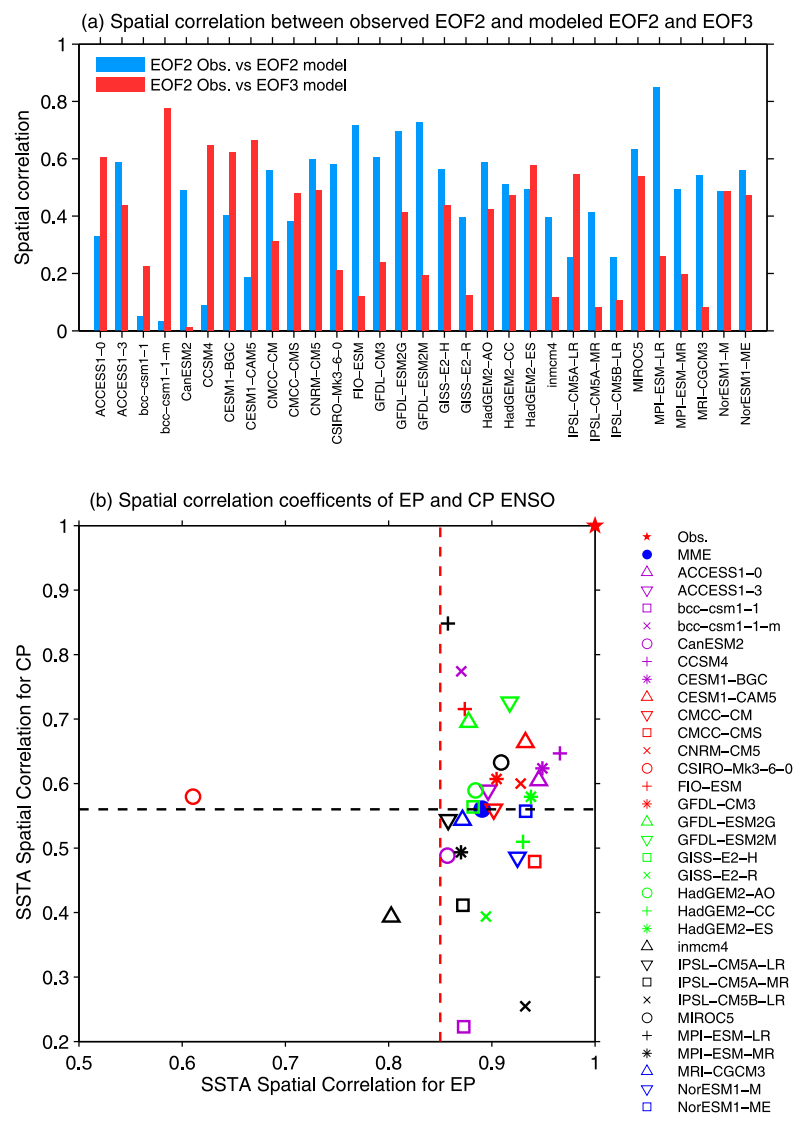

FIG. 2. (a) Spatial correlation coefficients between the observed EOF2 and simulated EOF2 (red bars), as well as those between the observed EOF2 and the simulated EOF3 (blue bars) from historical runs of each of the 31 CMIP5 climate models. (b) Scatterplots of spatial correlations between the observed and modeled EP and CP El Niño SST anomaly patterns. The red (black) dashed line denotes the threshold value of $+0.85(+0.65)$ of the spatial correlation coefficient for EP (CP) El Niño, based on which the best models are chosen. See text for details.

change might modulate the characteristics of El Niño based on their future climate projections. Using the 17 selected CMIP5 models (see section 3a), EOF analyses of SST in their future climate projections were performed. Figures $3 \mathrm{c}$ and $3 \mathrm{~d}$ depict the MME averages of SST anomalies associated with EP and CP El Niño modes from 2050 to 2099 under the RCP8.5 scenario, respectively. First, the projected EP and CP El Niño SST patterns were found to be very similar to those from the historical simulations (Figs. 3a,b). In the following, principal components of EOF modes corresponding to $\mathrm{EP}$ and CP El Niño are referred to as the EP index and the CP index, respectively. Since both the EP and CP El Niño reach their peaks in boreal winter (Kao and $\mathrm{Yu}$ 2009), in each model, EP El Niño (CP El Niño) events are identified whenever the standardized NovemberMarch (NDJFM) mean EP (CP) index is greater than
$1.0(0.8)$ standard deviation and is also greater than the concomitant CP (EP) index, to avoid the likely impacts of the mixed events. Also, following Feng et al. (2011, 2016), some CP El Niño events identified this way are discarded because they are all characterized by a strong negative SSTA in the eastern Pacific and a very weak positive SSTA in the central Pacific, similar to the EP type La Niña cases. Further inspection indicates that both the observed and modeled EP and CP El Niño events have their peak phases in boreal winter (not shown). Results for the frequencies of EP and $\mathrm{CP} \mathrm{El}$ Niño events, as well as their ratios, during the present climate and future climate conditions for each of the 17 models are summarized in Table 2 and Fig. 4. It can be seen that the MME mean CP-EP El Niño ratio does not change much from the present to the future climate, and the difference between the historical run and RCP8.5 scenario is smaller than the intermodel standard deviation. Aggregating results from all 17 selected models, the CP-EP El Niño ratio is reduced in the seven members [ACCESS1.0, CESM1(CAM5), CMCC-CM, GFDL CM3, GFDL-ESM2M, GISS-E2-H, and MIROC5] under a warmer climate, while it is significantly increased in the eight models [ACCESS1.3, BCC_CSM1.1(m), CCSM4, CESM1(BGC), CNRM-CM5, FIO-ESM, HadGEM2-AO, and HadGEM2-ES]. The remaining models have the same frequencies of EP and CP El Niño events in the present and future climate (see Table 2). Therefore, great uncertainty exists in the projected change of the CP-EP El Niño ratio. Using IPCC AR4 future climate projections, Yeh et al. (2009) indicated that the frequency from $\mathrm{CP}$ - to EP-type El Niño will increase under global warming. Their results, however, are based on only 11 models and different definitions of El Niño flavors. Our finding is consistent with a more recent study (Power et al. 2013), which suggested that there is no consensus on the projected change of such ENSO characteristics using models participating in CMIP5.

To further examine how climate change might impact the magnitude of El Niño, composite SST anomalies were also computed based on the selected 17 models. Figure 5 depicts the MME mean SST maps in boreal winter in the historical and RCP8.5 runs for the EP and CP El Niño years, together with the intermodel consistency of these results. For EP El Niño, the historical and RCP8.5 SST composites give similar spatial patterns but with different amplitudes; particularly, both are characterized by warm SST anomalies east of the date line, with the strongest positive signals located in the eastern tropical Pacific (Figs. 5a,c). The projected changes of EP El Niño SST anomalies, however, exhibit a decrease of their magnitude in the tropical Pacific; this is especially 
(a) Historical, EP El Nino (Corr. = 0.95)

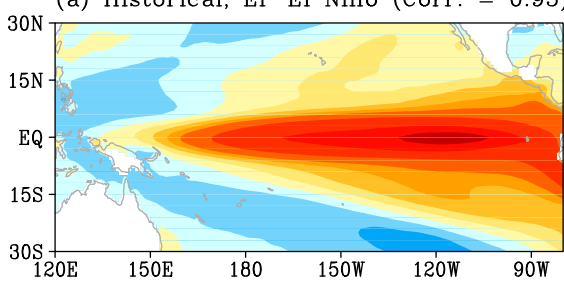

(c) RCP8.5, EP El Nino

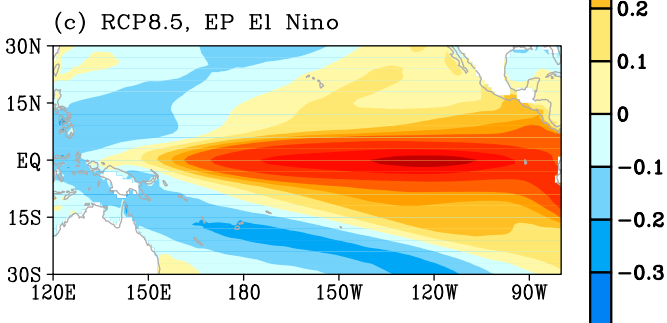

(b) Historical, CP El Nino (Corr. = 0.84)

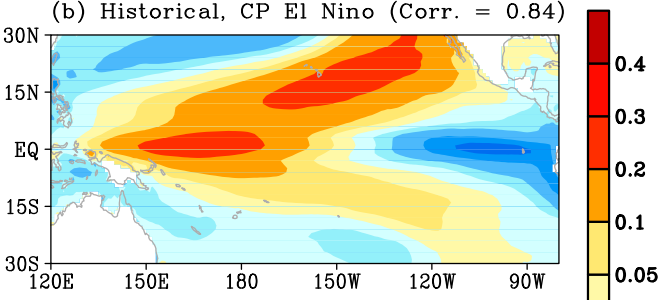

(d) RCP8.5, CP El Nino

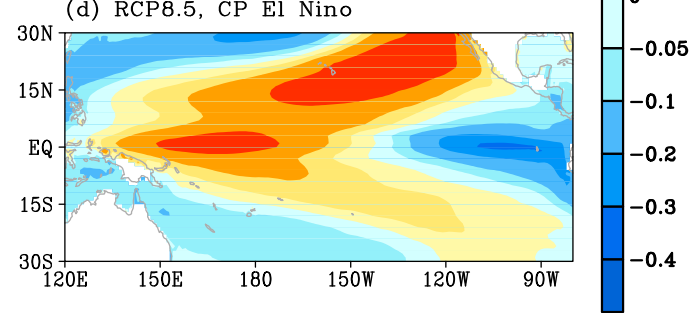

FIG. 3. MME mean of tropical Pacific SST anomalies associated with (a),(c) EP and (b),(d) CP El Niño (K) calculated from (a),(b) the historical runs during the 1950-99 period and (c),(d) RCP8.5 runs during the 205099 period based on 17 selected CMIP5 models. SST anomalies are computed as for those in Fig. 1. Spatial correlation coefficients between the observed and model-simulated SST patterns for the EP and CP El Niño during the historical period are also shown in parentheses at the top of (a) and (b).

so in the eastern equatorial Pacific and extending to the South American coast, with maximum reduction of warm SST reaching $-0.25 \mathrm{~K}$ (Fig. 5e). The intermodel consistency is greater than $70 \%$ in the tropical Pacific Ocean, suggesting that such reduced EP El Niño SST signals are robust among the selected models. This is consistent with the result reported by $\mathrm{Kim}$ and $\mathrm{Yu}$ (2012), based on different methods. For CP El Niño events, recurrent tropical Pacific SST anomalies in future are similar to those in the historical runs, albeit with different magnitudes (Figs. 5b,d). However, the agreement on future changes of SST anomalies in CP El Niño is much less widespread compared with the EP El Niño case, indicating rather large uncertainties in future projections of the CP El Niño intensity. It is noteworthy that the intermodel consistencies (larger than $70 \%$ ) can still be discerned in the eastern off-equatorial Pacific of both hemispheres. This could be related to changes of the local meridional circulation, which is able to influence CP El Niño occurrences (Yu et al. 2010; Yu and Kim 2011; Xu et al. 2013).

Results presented in this section demonstrate that the responses of the two types of El Niño to a warmer background climate can be rather different in the CMIP5 models. Most models give a decrease of EP El Niño intensity in their future climate projections, while there are no robust signals of the change in CP El Niño SST from the same sets of model simulations. Finally, these climate models reach no consensus on the change of relative frequency from CP to EP El Niño under global warming.

\section{Robust changes of the tropical precipitation associated with EI Niño}

\section{a. El Niño-related precipitation anomalies}

Tropical precipitation is one of the most important factors altering water resources in the tropics and in other parts of the globe (Alexander et al. 2002). Its variability can be a function of SST anomalies and hence is strongly influenced by ENSO (McPhaden et al. 2006). Following Xiang et al. (2013), five events were chosen for CP El Niño (1991/92, 1994/95, 2002/03, 2004/05, and 2009/10) and four events for EP El Niño (1982/83, 1986/ 87, 1997/98, and 2006/07) over the period 1979-2010. The composites of boreal winter mean anomalous precipitation for these EP and CP El Niño events are depicted in Figs. $6 \mathrm{a}$ and $6 \mathrm{~b}$. From observations, the zonal dipole of precipitation anomalies is seen in the deep tropics during EP El Niño, with a wet maximum centered near $150^{\circ} \mathrm{W}$ and a dry zone in the western tropical Pacific (Fig. 6a). During CP El Niño events, a tripole precipitation pattern is found, with the wet center mainly located near the date line and suppressed precipitation found over the eastern and the western tropical Pacific (Fig. 6b). The MME mean anomalous precipitation for EP and CP El Niño in boreal winter were computed to address how different types of $\mathrm{El}$ Niño may affect tropical precipitation anomalies in the future climate. Results are presented in Figs. $6 \mathrm{c}-\mathrm{h}$, together with the intermodel consistency of changes in the El Niño-related precipitation variability. In the historical runs, during EP El Niño events, positive anomalous 
TABLE 2. Numbers of EP and CP El Niño events that occur during the 1950-99 period in the historical runs and the 2050-99 projections under RCP8.5 in parentheses, as well as the CP-EP El Niño ratio in these epochs, based on the 17 selected CMIP5 models. Numbers with boldface font indicate an increase of the CP-EP El Niño ratio comparing the 2050-99 projections under RCP8.5 to the 1950-99 period in the model runs.

\begin{tabular}{lccc}
\hline \hline \multicolumn{1}{c}{ Model } & EP El Niño events & CP El Niño events & CP-EP El Niño ratio \\
\hline ACCESS1.0 & $6(9)$ & $9(11)$ & $1.50(1.22)$ \\
ACCESS1.3 & $7(8)$ & $9(11)$ & $\mathbf{1 . 2 9}(\mathbf{1 . 3 8})$ \\
BCC_CSM1.1(m) & $6(8)$ & $7(12)$ & $\mathbf{1 . 1 7}(\mathbf{1 . 5 0})$ \\
CCSM4 & $8(6)$ & $13(11)$ & $\mathbf{1 . 6 3}(\mathbf{1 . 8 3})$ \\
CESM1(BGC) & $7(8)$ & $8(10)$ & $\mathbf{1 . 1 4}(\mathbf{1 . 2 5})$ \\
CESM1(CAM5) & $9(11)$ & $11(9)$ & $1.22(0.82)$ \\
CMCC-CM & $7(7)$ & $10(6)$ & $1.43(0.86)$ \\
CNRM-CM5 & $9(12)$ & $7(10)$ & $\mathbf{0 . 7 8}(\mathbf{0 . 8 3})$ \\
FIO-ESM & $13(9)$ & $12(13)$ & $\mathbf{0 . 9 2}(\mathbf{1 . 4 4})$ \\
GFDL CM3 & $5(7)$ & $9(10)$ & $1.80(1.43)$ \\
GFDL-ESM2G & $6(6)$ & $9(9)$ & $1.50(1.50)$ \\
GFDL-ESM2M & $10(7)$ & $11(6)$ & $1.10(0.86)$ \\
GISS-E2-H & $7(8)$ & $12(10)$ & $1.71(1.25)$ \\
HadGEM2-AO & $9(7)$ & $11(11)$ & $\mathbf{1 . 2 2}(\mathbf{1 . 5 7})$ \\
HadGEM2-ES & $9(5)$ & $8(10)$ & $\mathbf{0 . 8 9}(\mathbf{2 . 0 0})$ \\
MIROC5 & $7(7)$ & $11(10)$ & $1.57(1.43)$ \\
MPI-ESM-LR & $7(8)$ & $7(8)$ & $1.00(1.00)$ \\
\hline
\end{tabular}

precipitation is located in the deep tropics east of $140^{\circ} \mathrm{E}$, and its maximum is centered near the date line, while negative anomalies are found in the western Pacific (Fig. 6c). Whereas, during CP El Niño events, precipitation is enhanced over the western Pacific near $160^{\circ} \mathrm{E}$ but is suppressed in the eastern equatorial Pacific (Fig. 6d). These results from the historical runs indicate that the CMIP5 models can capture the typical precipitation patterns associated with two types of El Niño but with obvious westward shifts of precipitation anomalies compared to observations. Note that biases of precipitation amplitudes and locations for $\mathrm{CP}$ El Niño are much larger than those for EP El Niño cases (see Figs. S3 and S4 in the supplementary material), suggesting that models are more capable of reproducing the observed EP El Niño precipitation anomalies, but less so for CP El Niño. It is also noteworthy that the precipitation response to EP El Niño is stronger than that to CP El Niño events (Figs. 6a-d), implying an asymmetry in amplitude of precipitation anomalies between the two types of El Niño in both the observations and the historical runs.

For precipitation anomalies associated with the future projected El Niño, they generally resemble their counterparts in the historical runs with modified magnitudes for both EP and CP El Niño (Figs. 6e,f). There is also reasonably high consistency among models regarding future changes of precipitation over the tropical Pacific (Figs. 6g,h). This is indeed remarkable in light of the rather uncertain changes of El Niño-related SST anomalies (Fig. 5). During EP El Niño events, robust increase (decrease) of equatorial precipitation is settled near the equator east of about $170^{\circ} \mathrm{E}$ (over the western tropical Pacific) (Fig. 6g), while precipitation is suppressed evidently near the intertropical convergence zone (ITCZ), which shifts equatorward in response to the enhanced equatorial SST under global warming (Xie et al. 2010). For CP El Niño, enhanced dry signals with intermodel consistency larger than $70 \%$ are located in the eastern equatorial Pacific, flanked by the significant increased rainfall on its subtropical sides (Fig. 6h). As shall be demonstrated later, this is probably related to the modified local Hadley cell over the central-eastern Pacific, which is important for the onset and evolution of CP El Niño events, as proposed by $\mathrm{Yu}$ et al. (2010) and Xu et al. (2013). Li et al. (2015) suggested almost all CMIP5 models suffer from a

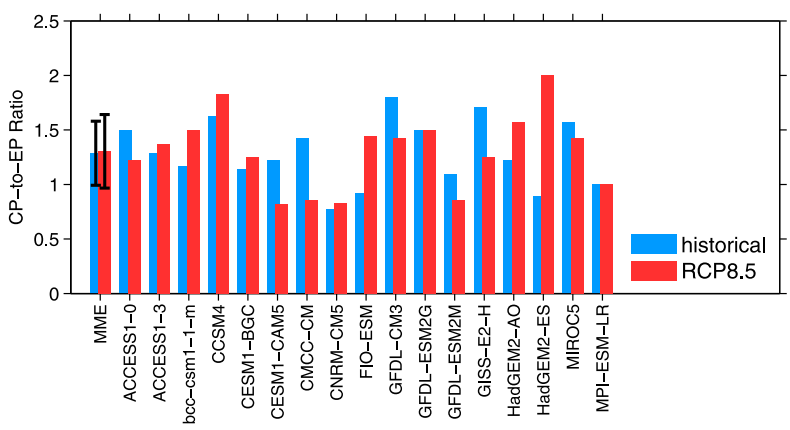

FIG. 4. Ratio of frequency for CP-to-EP El Niño events in the historical run (blue bars) and that based on 2050-99 future projections under the RCP8.5 scenario (red bars) from each of the 17 best CMIP5 climate models. MME mean results are also shown (see leftmost bars), together with the corresponding intermodel spreads (defined as one standard deviation of individual model values), as indicated by black lines. 
(a) EP, SST (historical)

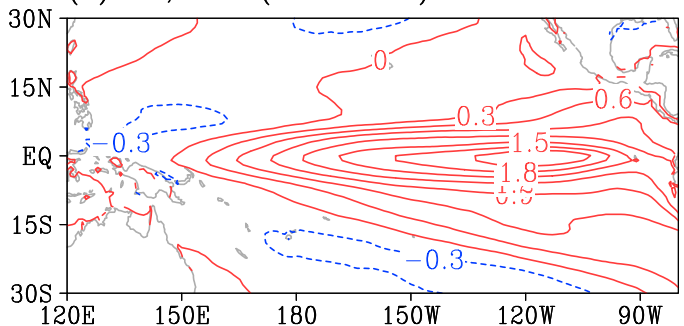

(c) EP, SST (RCP8.5)

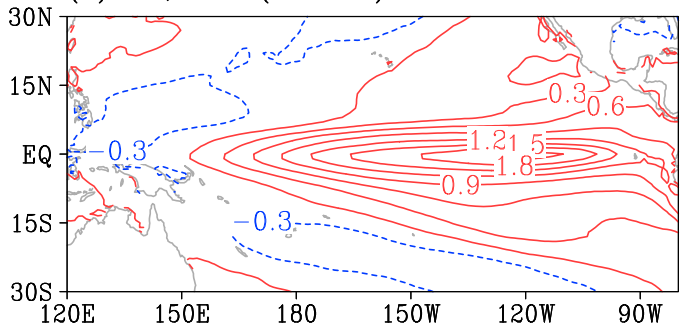

(e) EP, Diff. SST (RCP8.5-Hist)

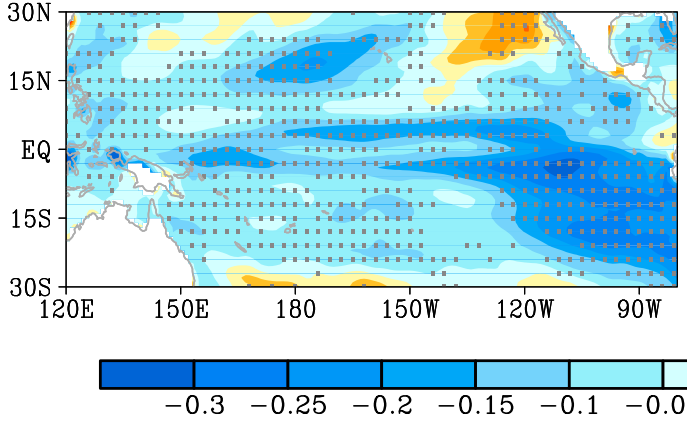

(b) CP, SST (historical)

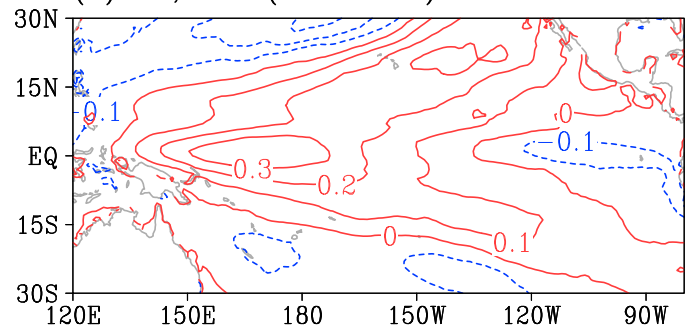

(d) CP, SST (RCP8.5)

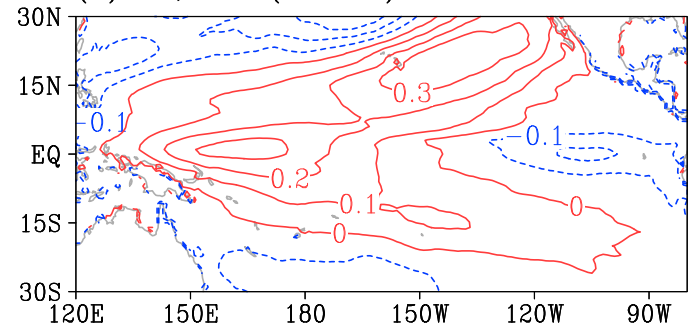

(f) CP, Diff. SST (RCP8.5-Hist)

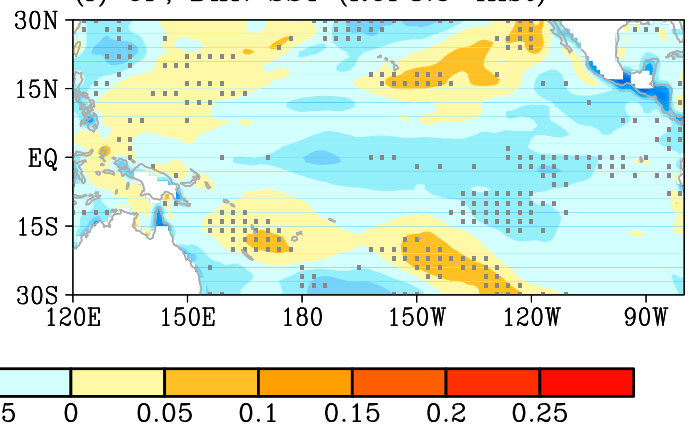

FIG. 5. MME averages of the NDJFM anomalous SST composites (contours; K) during (a),(c) EP and (b),(d) CP El Niño years from (a),(b) the historical runs and (c),(d) projections under RCP8.5 from the 17 selected CMIP5 models. Differences between the MME mean SST composites for the RCP8.5 2050-99 projection and those for the historical runs for EP and CP El Niño events are given in (e) and (f), respectively (shading; K). Gray dots indicate locations over which more than $70 \%$ of models agree on the sign of SST difference between historical and future runs.

cool SST bias and excessive westward extension of equatorial Pacific cold tongue relative to observations. We have carried out further analysis and found that such model SST bias in the cold tongue, if any, does not affect the aforementioned results regarding CP El Niño-driven precipitation response in the eastern Pacific (not shown). In the meantime, the insignificant wetter-than-normal precipitation anomalies are confined over the western tropical Pacific between $150^{\circ} \mathrm{E}$ and $180^{\circ}$, where the CMIP5 model projections of SST and precipitation suffer large uncertainties (Figs. 5f and 6h). Overall, there are robust responses of the anomalous tropical precipitation that tend to follow a wet-get-wetter pattern, regardless of how the projected SST might change under global warming. This is especially the case for EP El Niño events. Finally, in view of the various methods proposed for identifying the two types of El Niño, we have repeated our analysis using two other ways for selecting EP and CP El Niño events from the model runs [viz., the Niño-3.4 index method (Kug et al. 2009; Yeh et al. 2009) and EPCP index method (Kao and Yu 2009; Yu et al. 2012)]. Results of the MME mean SST as well as projected changes of SST and precipitation patterns are found to be very similar to those just presented (not shown).

\section{b. Atmospheric overturning circulations}

Besides precipitation, we have also examined the El Niño-related atmospheric circulation variability and its different response to a warmer climate state. The velocity potential $\chi$ and divergent wind $\mathbf{V} \chi$ are suitable variables reflecting the large-scale features of divergent motions (Tanaka et al. 2004). The velocity potential $\chi$ is calculated using the horizontal wind vector $\mathbf{V}$ following the definition of Krishnamurti (1971): 

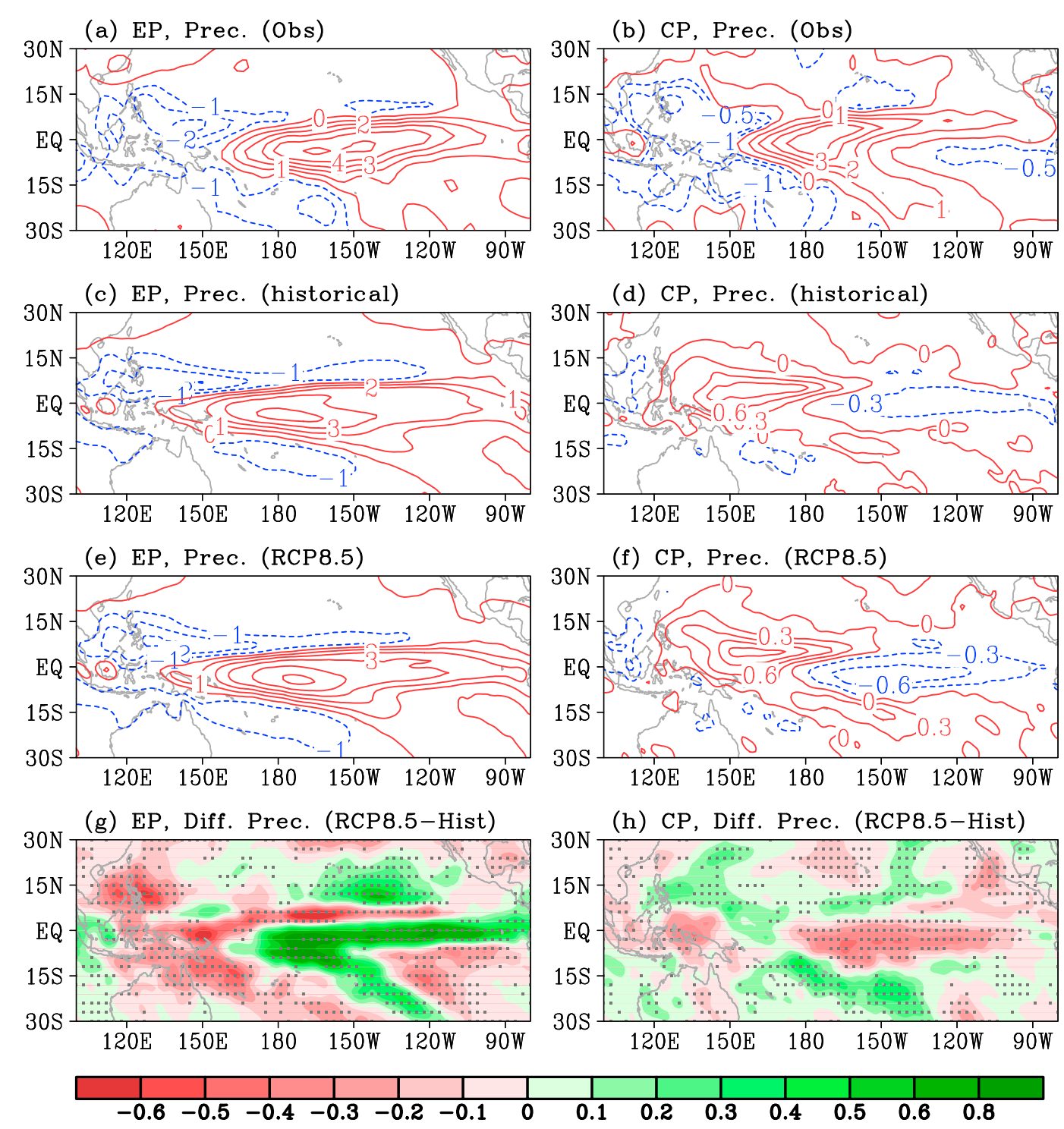

FIG. 6. Composites of the observed NDJFM anomalous precipitation ( $\mathrm{mm} \mathrm{day}^{-1}$ ) for (a) EP El Niño and (b) CP El Niño events identified by Xiang et al. (2013) during 1979-2010. (c)-(h) As in Fig. 5, but for precipitation.

$$
D=\nabla \cdot \mathbf{V}=\nabla^{2} \chi
$$

where the divergent wind $\mathbf{V} \chi$ flows down the gradient (from high to low values) of the velocity potential. The latter can be computed by expanding the divergence $D$ into spherical harmonics in the spectral domain. Figure 7 depicts the MME mean velocity potential and divergent wind anomalies at $200 \mathrm{hPa}$ associated with $\mathrm{EP}$ and $\mathrm{CP} \mathrm{El}$ Niño in both historical runs and future projections under the RCP8.5 scenario, as well as the difference between these scenarios. In both the historical runs and future projections, during EP El Niño the anomalous upperlevel divergence center is located over the eastern tropical Pacific, while the strongest convergence anomalies are centered over the Maritime Continent (Figs. 7a,c); such divergent circulation is seen to correspond to the simulated EP El Niño SST anomalies. In contrast, for CP El Niño, upper-level divergence anomalies around $150^{\circ} \mathrm{E}$ are seen to collocate with warm SST, whereas anomalous convergences (and, by implication, sinking motions) are located east of Indochina and over the eastern equatorial Pacific extending into South America (Figs. 7b,d). Generally, upper-level divergence and convergence anomalies over the tropical Pacific for EP (CP) El Niño manifest a zonal dipole (tripole) pattern, in accordance with the underlying SST anomalies (Fig. 3). Compared with EP El Niño, the most prominent difference of CP El Niño-related upper-level 

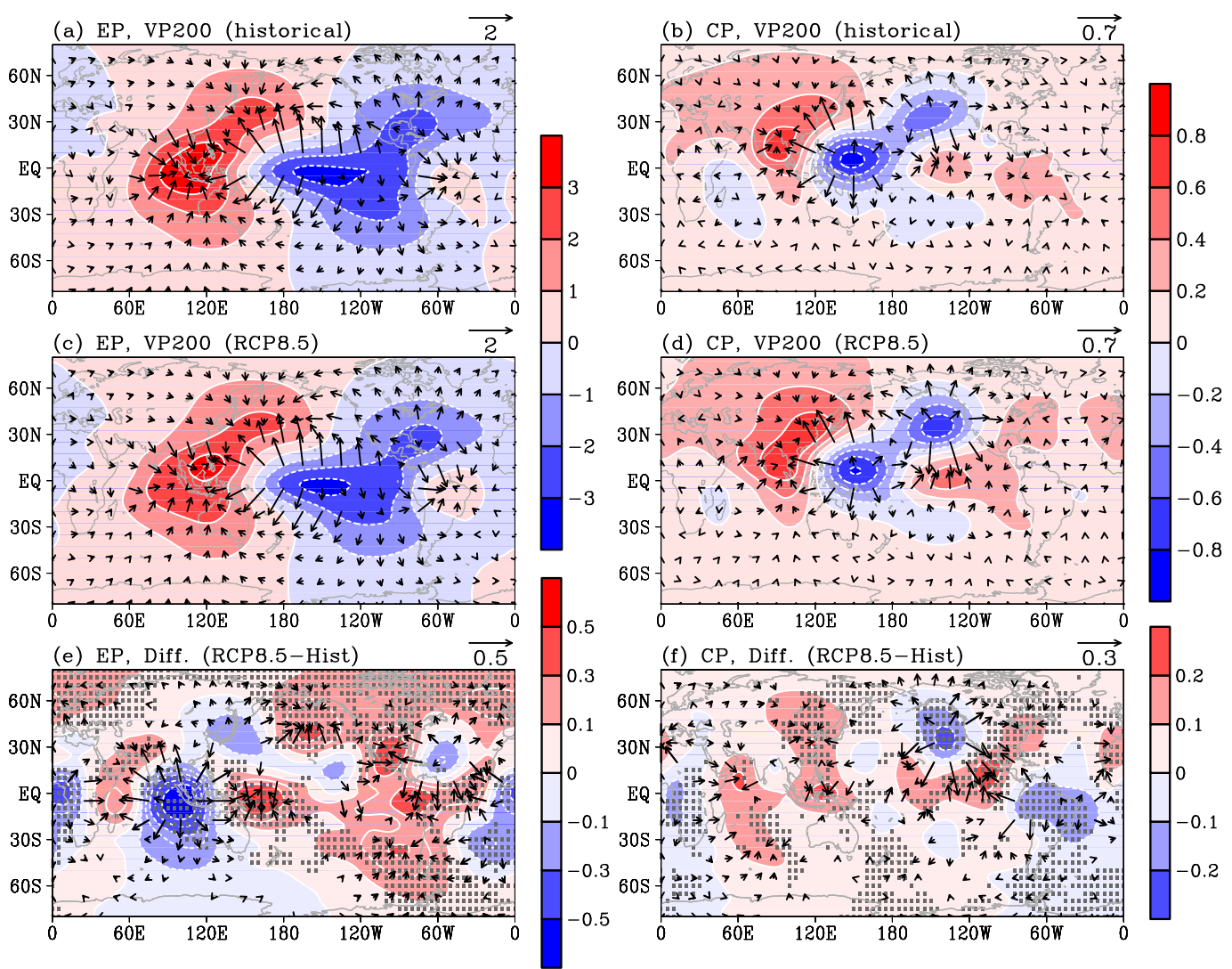

FIG. 7. As in Fig. 5, but for the 200-hPa velocity potential (VP200; shading; $10^{6} \mathrm{~m}^{2} \mathrm{~s}^{-1}$ ) and divergent wind (vectors; $\mathrm{m} \mathrm{s}^{-1}$ ). Black vectors (gray dots) in (e) and (f) indicate locations over which more than $70 \%$ of models agree on the sign of divergent wind (velocity potential) difference between historical and future runs.

circulation is featured by a strong divergent center located over the northeastern Pacific, highlighting a more meridionally oriented overturning circulation during $\mathrm{CP}$ El Niño events (Figs. 7b,d).

Inspection of climate projections from the 17 selected models revealed that, during EP El Niño the anomalous upper-level velocity potential over the eastern equatorial Indian Ocean tends to be more negative (with model agreement of $70 \%$ ) in response to a warmer climate (Fig. 7e), which means the upper-level convergence over the Indian sector is projected to diminish. In the meantime, robust increase of the positive upper-level velocity potential anomalies is observed near the equator between $140^{\circ} \mathrm{E}$ and $60^{\circ} \mathrm{W}$ (Fig. 7e), indicating that the magnitude of the anomalous divergence will decrease in this region. Therefore, the zonal overturning circulation is weakened during EP El Niño under a warming climate. The case for $\mathrm{CP}$ El Niño, however, is less straightforward. Figure $7 \mathrm{f}$ shows that the upper-level divergence anomalies are enhanced over the northern central-eastern Pacific such that there is a strengthened meridional dipole structure between $180^{\circ}$ and $100^{\circ} \mathrm{W}$ in the North Pacific. It implies that the most prominent feature in the change of CP El Niño-related overturning circulation resembles a local Hadley cell anomaly over the eastern North Pacific, and these projected changes are consistent among the selected CMIP5 models.

Future changes in the overturning circulation can be better described by the vertical cross section of the anomalous divergent wind circulation near the equator (Fig. 8). It is observed that, during EP El Niño, the anomalous Walker circulation in both historical runs and future projections exhibits a single-cell structure over the equatorial Pacific (Figs. 8a,c), with its ascending branch over the central-eastern Pacific and descending one near $120^{\circ} \mathrm{E}$. Such an anomalous Walker cell tends to be weakened under global warming, with a widespread agreement (larger than 70\%) across the selected CMIP5 models (Fig. 8e). For CP El Niño, however, the associated divergent circulation shows a double-cell pattern over the equatorial Pacific, with an ascending branch from near $150^{\circ} \mathrm{E}$ to the date line, flanked by the descending branches west of $130^{\circ} \mathrm{E}$ and east of $160^{\circ} \mathrm{W}$ (Figs. 8b,d). Projected changes of the Walker circulation imply a stronger sinking over the equatorial eastern Pacific and a confined region between $120^{\circ}$ and $150^{\circ} \mathrm{E}$ 

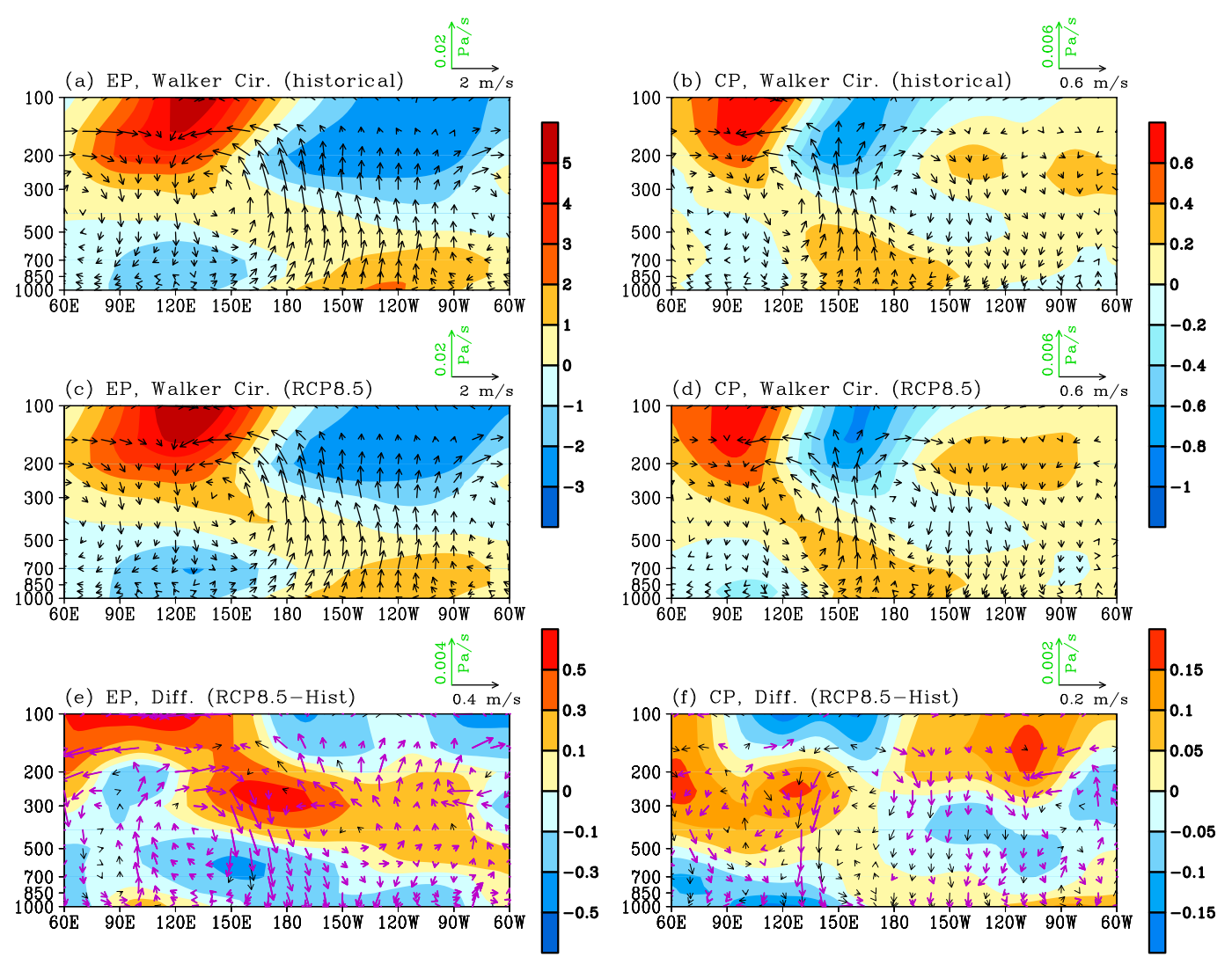

FIG. 8. As in Fig. 5, but for the anomalous Walker circulation (vectors; zonal divergent wind and vertical pressure velocity, see scale at the top right of each panel) and velocity potential (shading; $10^{6} \mathrm{~m}^{2} \mathrm{~s}^{-1}$ ) averaged over $5^{\circ} \mathrm{S}-5^{\circ} \mathrm{N}$. The vertical pressure velocity is multiplied by a factor of -50 for clarity. Purple vectors in (e) and (f) indicate agreement among $70 \%$ of models or more on the sign of change in either the zonal or vertical component of wind vectors.

(Fig. 8f). Therefore, the descending branch over the eastern Pacific associated with CP El Niño tends to strengthen in the future climate, whereas the rising branch found near $150^{\circ} \mathrm{E}$ tends to be more confined geographically with a slightly smaller zonal extent.

As mentioned before, the anomalous Hadley cell over the eastern tropical Pacific could be important for the evolution of CP El Niño. To understand how such a local Hadley cell responds to a changing background climate and how that may, in turn, impact the atmospheric circulation during CP El Niño, the associated divergent wind vectors and velocity potential anomalies averaged over $180^{\circ}-100^{\circ} \mathrm{W}$ are presented in Fig. 9. During CP El Niño events in both historical runs and future projections, a local meridional overturning cell can be observed over the eastern tropical Pacific with its sinking (rising) branch over the $10^{\circ} \mathrm{S}-10^{\circ} \mathrm{N}$ region (extratropical North Pacific) (Figs. 9a,b), consistent with the composite maps for the $200-\mathrm{hPa}$ anomalous divergent motion (Figs. 7b,d). It is noteworthy that, under a warmer background climate, projected changes of such a local Hadley cell have the same spatial pattern as that found in the historical runs (Fig. 9c). In other words, the local Hadley circulation over the eastern Pacific during the CP El Niño tends to be strengthened under global warming, in accordance with the underlying SST anomalies (Fig. 5f). Therefore, it seems that, in addition to the wet-get-wetter mechanism, which leads to even drier anomalies over the eastern Pacific, the stronger sinking associated with a modified Hadley cell will further suppress precipitation over the eastern Pacific during CP El Niño events.

Consequently, in the future climate the EP El Niñorelated precipitation anomalies will be increased over the eastern-central equatorial Pacific, despite the fact that warm SST anomalies and ascending motion are weakened (Figs. 5e and 6e). Such contradiction may be ascribed to the future changes in the mean state of tropical precipitation. Power et al. (2013) demonstrated that changes of El Niño-driven precipitation may instead be primarily due to a nonlinear response to the background-state SST under global warming. We have 


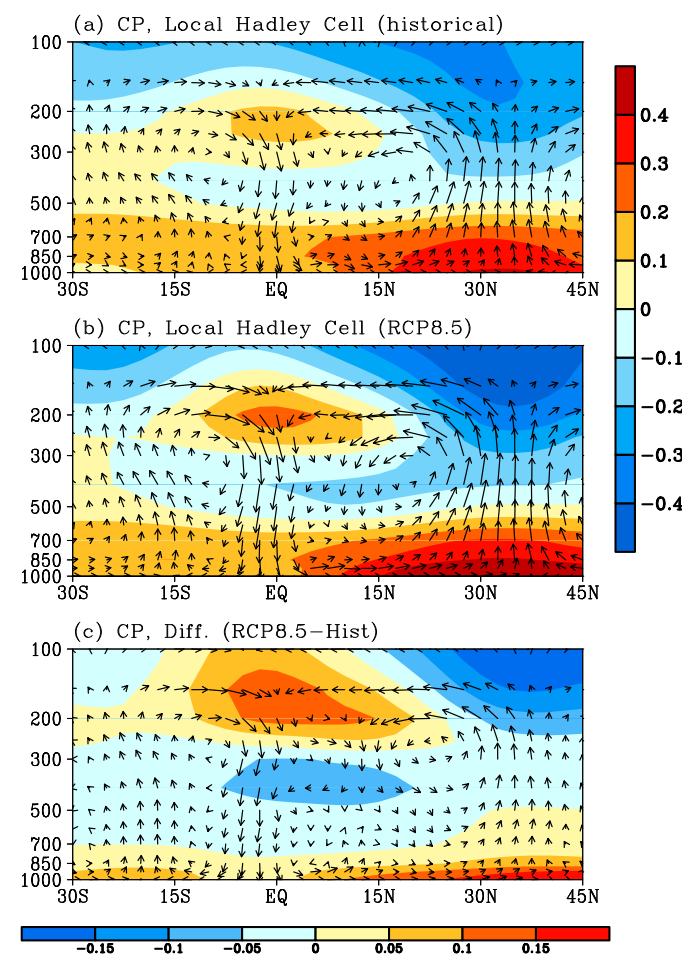

FIG. 9. MME averages of the NDJFM anomalous local Hadley circulation (vectors; meridional divergent wind and vertical pressure velocity, scale vectors to the far right of each panels) and velocity potential composites (shading; $10^{6} \mathrm{~m}^{2} \mathrm{~s}^{-1}$ ) averaged over the central-eastern Pacific region of $180^{\circ}-100^{\circ} \mathrm{W}$ during the CP El Niño years from (a) the historical runs, (b) 2050-99 projections under RCP8.5 from the 17 best CMIP5 models, and (c) their differences. Vertical pressure velocity is multiplied by a factor of -50 for clarity.

examined the mean state of NDJFM precipitation over the tropical Pacific in both historical runs and future projections (Figs. 10a and 10b, respectively). There is indeed an accelerated hydrological cycle confined over a deep tropical belt in the future climate (Fig. 10c). To assess the robustness of such an increase, we have further examined the NDJFM precipitation averaged between $5^{\circ} \mathrm{N}$ and $10^{\circ} \mathrm{S}$. It was found that their futureminus-present differences based on the MME mean, as well as those from the majority of models, are all positive over the Pacific sector (see Fig. S5 in the supplementary material). The future projected mean precipitation over the deep tropics is stronger than that in the present climate. This is in line with the picture painted by Held and Soden (2006) and Watanabe et al. (2014), in which the mean hydrological cycle becomes stronger in spite of a weakened tropical circulation under a warmer background climate. Over the far eastern Pacific, this wetter region is straddled by drier zones in both hemispheres centered at about $120^{\circ} \mathrm{W}$

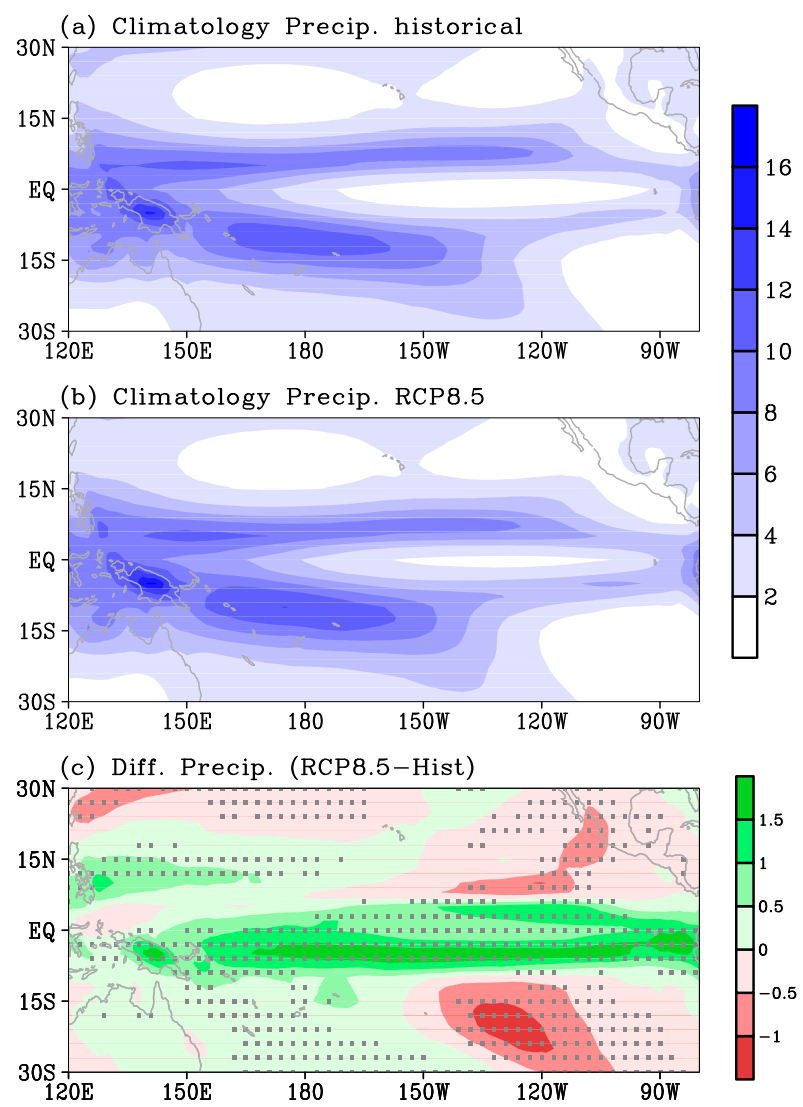

FIG. 10. MME average of the NDJFM climatological precipitation $\left(\mathrm{mm} \mathrm{day}^{-1}\right)$ over the tropical Pacific from (a) the historical runs, (b) 2050-99 projections under RCP8.5 from the 17 selected CMIP5 models, and (c) their differences. Gray dots in (c) indicate locations over which more than $70 \%$ of models agree on the sign of SST difference between historical and future runs.

(Fig. 10c), consistent with the position of the local Hadley cell and its associated stronger sinking to the north of climatological ITCZ location over the eastern Pacific. Moreover, the mean precipitation in NDJFM is projected to increase over the subtropical western $\mathrm{Pa}$ cific in the Southern Hemisphere (Fig. 10c); this is related to the slightly southwestward shift of the future SPCZ in this season. It suggests that precipitation anomalies associated with future changes in EP El Niño may be more sensitive to changes of the basic-state precipitation near the equator; thus, the precipitation signals are enhanced even though the corresponding SST anomalies tend to be weakened.

\section{Summary and discussion}

Despite intensive discussions on how El Niño characteristics might change under a warmer climate, there are relatively few studies investigating $\mathrm{EP}$ and $\mathrm{CP} \mathrm{El}$ Niño-driven tropical precipitation variability in the 
future climate. Here we have discussed how future climate change might modulate the two types of El Niño, with a particular emphasis on their associated tropical atmospheric circulation and precipitation impacts. The capability of 31 CMIP5 models in simulating ENSO diversity was first evaluated by carrying out EOF analyses on the interannually varying tropical Pacific SST in their historical runs. In general, the two types of El Niño can be reproduced by the CMIP5 models, albeit with different degrees of realism. While the majority of CMIP5 models show good skill in capturing the observed EP El Niño SST variability, only $55 \%$ (17 out of 31 ) models can reasonably simulate $\mathrm{CP}$ El Niño, indicating that CMIP5 models are more capable of simulating the EP El Niño than the CP El Niño.

Our analyses also demonstrate that the responses of the two types of ENSO flavors to a warmer climate background are distinct. Through examining the subset of CMIP5 models capable of reproducing both types of ENSO, EP El Niño is found to be weakened in the future projection from 2050 to 2099 under the RCP8.5 scenario. However, the same set of models indicates no robust change in the intensity of CP El Niño in future. There is also a lack of consensus among these models on the changes in relative frequency from CP to EP El Niño events under global warming; the latter result is thus different from that reported by Yeh et al. (2009). One possible reason for such a discrepancy could be the different datasets and definitions being used.

Interestingly, models do indicate robust changes in both EP and CP El Niño-driven tropical atmospheric circulation and precipitation variability in the future climate. For EP El Niño, its associated modulation on the hydrological cycle tends to be exacerbated such that there are stronger positive (negative) precipitation anomalies in the eastern-central (western) tropical Pacific under a warmer background climate. At the same time, its related overturning circulation anomalies in the deep tropical Indo-Pacific region appear to diminish. The future changes in circulation during EP El Niño events are reminiscent of those happening to the time mean tropical circulation: namely, weakening of the mean Walker circulation due to global warming, as reported by a number of researchers (e.g., Vecchi and Soden 2007; Power and Kociuba 2011). Using our selected models, we have also investigated the projected changes of the time mean Walker circulation. Figure S4 gives the zonal and vertical velocity averaged over $5^{\circ} \mathrm{S}-5^{\circ} \mathrm{N}$ for both historical and future climate runs and also their difference. It is clear that changes in the Walker circulation are largely opposite to its historically simulated climatology, indicating suppressed rising (descending) over the Indo-Pacific warm pool (eastern tropical Pacific) region. The intermodel consistency of the projected Walker circulation slowdown means that its change is robust. The similarity of slowdown between the mean Walker cell response and the response of the anomalous Walker overturning during ENSO to global warming suggests the same dynamics that gives rise to the so-called wet-get-wetter patterns is responsible for circulation changes in both cases.

For CP El Niño, again changes of the anomalous precipitation largely conform to such a wet-get-wetter picture. Actually, there is even stronger sinking motion over the central-eastern tropical Pacific such that the anomalous overturning acts to reinforce the dry signal there during CP El Niño events in the future climate. This can be attributed to a strengthened local Hadley cell over the eastern North Pacific. Thus, under global warming, both an accelerated basic-state hydrological cycle as well as stronger anomalous subsidence operate together to further suppress precipitation over the central-eastern Pacific when CP El Niño occurs.

The future projected changes of the amplitudes of anomalous SST, precipitation, and Walker circulation for the two types of El Niño exhibit significant differences. Two possible explanations might account for such differences. First, CP and EP types of El Niño have a pronounced asymmetry in their amplitudes shown in Figs. 5 and 6 , which can be attributed to the strength asymmetry of the Bjerknes feedback. Thus, CP El Niño tends to be associated with weaker SST anomalies than EP El Niño, and CMIP5 models generally can depict the asymmetry in amplitude between EP and CP El Niño events (Fang et al. 2015). The fact that CP El Niño has weaker amplitude may result in its changes under global warming not being robust. Second, in comparison with EP El Niño, the representation of $\mathrm{CP}$ El Niño in models can be severely biased (Fang et al. 2015). In particular, some CMIP5 models may not be able to successfully simulate tropical-extratropical linkages at the surface (Yu et al. 2010; Yu and Kim 2011) and in the subsurface (Wen et al. 2014) Pacific Ocean, which have been proposed to play a role in triggering CP El Niño events. It should also be pointed out that this study mainly focuses on the interannual tropical precipitation variability associated with ENSO. Previous studies suggest that CP El Niño occurrence seems to be closely associated with decadal variability in the Pacific (Ashok et al. 2007; Lee and McPhaden 2010; Xu et al. 2012; Xiang et al. 2013); such a linkage merits further studies. More analyses and model experiments are needed to elucidate the mechanisms through which various circulation elements can influence the ENSO-related anomalous precipitation. Research in these directions, including how a warmer background climate might modulate these linkages, will be reported elsewhere. 
Acknowledgments. This study was jointly supported by the Funds for Creative Research Groups of China (Grant 41521005), the Special Fund for Public Welfare Industry (Grant GYHY201506013), the Strategic Priority Research Program of the Chinese Academy of Sciences (Grant XDA11010301), the Chinese University of Hong Kong Direct Grant (Grant 4053113), the National Natural Science Foundation of China (Grants 41406033, 41475057, and 41505049), and the CAS/SAFEA International Partnership Program for Creative Research Teams. We also acknowledge the climate modeling groups (listed in Table 1) for producing and making available their model output, WCRP's Working Group on Coupled Modelling (WGCM) for organizing the CMIP5 analysis activity, the Program for Climate Model Diagnostics and Intercomparison (PCMDI) for collecting and archiving the CMIP5 multimodel data, and the U.S. Department of Energy for supporting these datasets in partnership with the Global Organization for Earth System Science Portals.

\section{REFERENCES}

Adler, R. F., and Coauthors, 2003: The Version-2 Global Precipitation Climatology Project (GPCP) monthly precipitation analysis (1979-present). J. Hydrometeor., 4, 1147-1167, doi:10.1175/1525-7541(2003)004<1147:TVGPCP>2.0.CO;2.

Alexander, M. A., I. Bladé, M. Newman, J. R. Lanzante, N.-C. Lau, and J. D. Scott, 2002: The atmospheric bridge: The influence of ENSO teleconnections on air-sea interaction over the global oceans. J. Climate, 15, 2205-2231, doi:10.1175/ 1520-0442(2002)015<2205:TABTIO > 2.0.CO;2.

Ashok, K., S. K. Behera, S. A. Rao, H. Weng, and T. Yamagata 2007: El Niño Modoki and its possible teleconnection. J. Geophys. Res., 112, C11007, doi:10.1029/2006JC003798.

_ C.-Y. Tam, and W. J. Lee, 2009: ENSO Modoki impact on the Southern Hemisphere storm track activity during extended austral winter. Geophys. Res. Lett., 36, L12705, doi:10.1029/ 2009GL038847.

_, C. Nagaraju, A. S. Gupta, and D. S. Pai, 2014: Decadal changes in the relationship between the Indian and Australian summer monsoons. Climate Dyn., 42, 1043-1052, doi:10.1007/ s00382-012-1625-4.

Banholzer, S., and S. Donner, 2014: The influence of different El Niño types on global average temperature. Geophys. Res. Lett., 41, 2093-2099, doi:10.1002/2014GL059520.

Cai, W., and T. Cowan, 2009: La Niña Modoki impacts Australia autumn rainfall variability. Geophys. Res. Lett., 36, L12805, doi:10.1029/2009GL037885.

— Niño events due to greenhouse warming. Nat. Climate Change, 4, 111-116, doi:10.1038/nclimate2100.

- , and Coauthors, 2015: ENSO and greenhouse warming. Nat. Climate Change, 5, 849-859, doi:10.1038/nclimate 2743 .

Chen, G., and C.-Y. Tam, 2010: Different impacts of two kinds of Pacific Ocean warming on tropical cyclone frequency over the western North Pacific. Geophys. Res. Lett., 37, L01803, doi:10.1029/2009GL041708.

Di Lorenzo, E., K. M. Cobb, J. Furtado, N. Schneider, B. T. Anderson, A. Bracco, M. Alexander, and D. Vimont, 2010:
Central Pacific warming El Niño and decadal climate change in the North Pacific. Nat. Geosci., 3, 762-765, doi:10.1038/ngeo984.

Fang, X.-H., F. Zheng, and J. Zhu, 2015: The cloud-radiative effect when simulating strength asymmetry in two types of El Niño events using CMIP5 models. J. Geophys. Res., 120, 4357-4369, doi:10.1002/2014JC010683.

Feng, J., and J. Li, 2011: Influence of El Niño Modoki on spring rainfall over south China. J. Geophys. Res., 116, D13102, doi:10.1029/2010JD015160.

, and - 2013: Contrasting impacts of two types of ENSO on the boreal spring Hadley circulation. J. Climate, 26, 47734789, doi:10.1175/JCLI-D-12-00298.1.

, L. Wang, W. Chen, S. K. Fong, and K. C. Leong, 2010: Different impacts of two types of Pacific Ocean warming on Southeast Asian rainfall during boreal winter. J. Geophys. Res., 115, D24122, doi:10.1029/2010JD014761.

, W. Chen, C.-Y. Tam, and W. Zhou, 2011: Different impacts of El Niño and El Niño Modoki on China rainfall in the decaying phases. Int. J. Climatol., 31, 2091-2101, doi:10.1002/ joc. 2217 .

_ — - and Y. Li, 2016: Asymmetry of the winter extra-tropical teleconnections in the Northern Hemisphere associated with two types of ENSO. Climate Dyn., doi:10.1007/ s00382-016-3196-2, in press.

Gupta, A. S., N. C. Jourdain, J. N. Brown, and D. Monselesan, 2013: Climate drift in the CMIP5 models. J. Climate, 26, 85978615, doi:10.1175/JCLI-D-12-00521.1.

Ham, Y.-G., Y. Jeong, and J.-S. Kug, 2015: Changes in independency between two types of El Niño events under a greenhouse warming scenario in CMIP5 models. J. Climate, 28, 7561-7575, doi:10.1175/JCLI-D-14-00721.1.

Held, I. M., and B. J. Soden, 2006: Robust responses of the hydrological cycle to global warming. J. Climate, 19, 5686-5699, doi:10.1175/JCLI3990.1.

Huang, P., S.-P. Xie, K. Hu, G. Huang, and R. Huang, 2013: Patterns of the seasonal response of tropical rainfall to global warming. Nat. Geosci., 6, 357-361, doi:10.1038/ngeo1792.

Kao, H.-Y., and J.-Y. Yu, 2009: Contrasting eastern-Pacific and Central-Pacific types of ENSO. J. Climate, 22, 615-632, doi:10.1175/2008JCLI2309.1.

Kim, S. T., and J.-Y. Yu, 2012: The two types of ENSO in CMIP5 models. Geophys. Res. Lett., 39, L11704, doi:10.1029/ 2012GL052006.

Krishnamurti, T. N., 1971: Tropical east-west circulations during the northern summer. J. Atmos. Sci., 28, 1342-1347, doi:10.1175/1520-0469(1971)028<1342:TEWCDT>2.0.CO;2.

Kug, J.-S., F.-F. Jin, and S.-I. An, 2009: Two types of El Niño events: Cold tongue El Niño and warm pool El Niño. J. Climate, 22, 1499-1515, doi:10.1175/2008JCLI2624.1.

, S.-I. An, Y.-G. Ham, and I.-S. Kang, 2010: Changes in El Niño and La Niña teleconnections over North PacificAmerica in the global warming simulations. Theor. Appl. Climatol., 100, 275-282, doi:10.1007/s00704-009-0183-0.

Larkin, N. K., and D. E. Harrison, 2005: On the definition of El Niño and associated seasonal average U.S. weather anomalies. Geophys. Res. Lett., 32, L13705, doi:10.1029/2005GL022738.

Lau, N.-C., and M. J. Nath, 1996: The role of the "atmospheric bridge" in linking tropical Pacific ENSO events to extratropical SST anomalies. J. Climate, 9, 2036-2057, doi:10.1175/ 1520-0442(1996)009<2036:TROTBI >2.0.CO;2.

Lee, T., and M. J. McPhaden, 2010: Increasing intensity of El Niño in the central-equatorial Pacific. Geophys. Res. Lett., 37, L14603, doi:10.1029/2010GL044007. 
Li, G., Y. Du, H. Xu, and B. Ren, 2015: An intermodel approach to identify the source of excessive equatorial Pacific cold tongue in CMIP5 models and uncertainty in observational datasets. J. Climate, 28, 7630-7640, doi:10.1175/JCLI-D-15-0168.1.

McPhaden, M. J., S. E. Zebiak, and M. H. Glantz, 2006: ENSO as an integrating concept in Earth science. Science, 314, 17401745, doi:10.1126/science.1132588.

Power, S. B., and G. Kociuba, 2011: What caused the observed twentieth-century weakening of the Walker circulation? J. Climate, 24, 6501-6514, doi:10.1175/2011JCLI4101.1.

— F. Felage, R. Colman, and A. Moise, 2012: Consensus on twenty-first-century rainfall projections in climate models more widespread than previously thought. J. Climate, 25, 3792-3809, doi:10.1175/JCLI-D-11-00354.1.

,-- C. Chung, G. Kociuba, and K. Keay, 2013: Robust twenty-first-century projections of $\mathrm{El}$ Niño and related precipitation variability. Nature, 502, 541-545, doi:10.1038/ nature 12580.

Rayner, N. A., D. E. Parker, E. B. Horton, C. K. Folland, L. V. Alexander, D. P. Rowell, E. C. Kent, and A. Kaplan, 2003: Global analyses of sea surface temperature, sea ice, and night marine air temperature since the late nineteenth century. J. Geophys. Res., 108, 4407, doi:10.1029/2002JD002670.

Su, J., T. Li, and R. Zhang, 2014: The initiation and developing mechanisms of central Pacific El Niños. J. Climate, 27, 44734485, doi:10.1175/JCLI-D-13-00640.1.

Tanaka, H. L., N. Ishizaki, and A. Kitoh, 2004: Trend and interannual variability of Walker, monsoon and Hadley circulations defined by velocity potential in the upper troposphere. Tellus, 56A, 250-269, doi:10.1111/j.1600-0870.2004.00049.x.

Taschetto, A. S., A. Sen Gupta, N. C. Jourdain, A. Santoso, C. C. Ummenhofer, and M. H. England, 2014: Cold tongue and warm pool ENSO events in CMIP5: Mean state and future projections. J. Climate, 27, 2861-2885, doi:10.1175/JCLI-D-13-00437.1.

Taylor, K. E., R. J. Stouffer, and G. A. Meehl, 2012: An overview of CMIP5 and the experiment design. Bull. Amer. Meteor. Soc., 93, 485-498, doi:10.1175/BAMS-D-11-00094.1.

van Vuuren, D., and Coauthors, 2011: The representative concentration pathways: An overview. Climatic Change, 109, 5-31, doi:10.1007/s10584-011-0148-z.

Vecchi, G. A., and B. J. Soden, 2007: Global warming and the weakening of the tropical circulation. J. Climate, 20, 43164340, doi:10.1175/JCLI4258.1.

Wang, B., R. Wu, and X. Fu, 2000: Pacific-East Asian teleconnection: How does ENSO affect East Asian climate? J. Climate, 13, 1517-1536, doi:10.1175/1520-0442(2000)013<1517: PEATHD $>2.0 . \mathrm{CO} ; 2$.

Wang, C., and X. Wang, 2013: Classifying El Niño Modoki I and II by different impacts on rainfall in southern China and typhoon tracks. J. Climate, 26, 1322-1338, doi:10.1175/ JCLI-D-12-00107.1.

Watanabe, M., Y. Kamae, and M. Kimoto, 2014: Robust increase of the equatorial Pacific rainfall and its variability in a warmed climate. Geophys. Res. Lett., 41, 3227-3232, doi:10.1002/ 2014GL059692.

Wen, C., A. Kumar, Y. Xue, and M. J. McPhaden, 2014: Changes in tropical Pacific thermocline depth and their relationship to ENSO after 1999. J. Climate, 27, 7230-7249, doi:10.1175/ JCLI-D-13-00518.1.

Weng, H., K. Ashok, S. K. Behera, S. A. Rao, and T. Yamagata, 2007: Impacts of recent El Niño Modoki on dry/wet conditions in the Pacific Rim during boreal summer. Climate Dyn., 29, 113-129, doi:10.1007/s00382-007-0234-0.
Wu, R., Z.-Z. Hu, and B. P. Kirtman, 2003: Evolution of ENSOrelated rainfall anomalies in East Asia. J. Climate, 16, 3742-3758, doi:10.1175/1520-0442(2003)016<3742:EOERAI >2.0.CO;2.

_ J. Chen, and W. Chen, 2012: Different types of ENSO influences on the Indian summer monsoon variability. J. Climate, 25, 903-920, doi:10.1175/JCLI-D-11-00039.1.

Xiang, B., B. Wang, and T. Li, 2013: A new paradigm for the predominance of standing central Pacific warming after the late 1990s. Climate Dyn., 41, 327-340, doi:10.1007/ s00382-012-1427-8.

Xie, S.-P., C. Deser, G. A. Vecchi, J. Ma, H. Teng, and A. T. Wittenberg, 2010: Global warming pattern formation: Sea surface temperature and rainfall. J. Climate, 23, 966-986, doi:10.1175/2009JCLI3329.1.

Xu, K., C. Zhu, and J. He, 2012: Linkage between the dominant modes in Pacific subsurface ocean temperature and the two type ENSO events. Chin. Sci. Bull., 57, 3491-3496, doi:10.1007/s11434-012-5173-4.

,,-- and -2013 : Two types of El Niño-related Southern Oscillation and their different impacts on global land precipitation. Adv. Atmos. Sci., 30, 1743-1757, doi:10.1007/ s00376-013-2272-3.

__ J. Su, and C. Zhu, 2014: The natural oscillation of two types of ENSO events based on analyses of CMIP5 model control runs. Adv. Atmos. Sci., 31, 801-813, doi:10.1007/ s00376-013-3153-5.

Yeh, S.-W., J.-S. Kug, B. Dewitte, M.-H. Kwon, B. P. Kirtman, and F.-F. Jin, 2009: El Niño in a changing climate. Nature, 461, 511-514, doi:10.1038/nature08316.

,$- \ldots$, and S.-I. An, 2014: Recent progress on two types of El Niño: Observations, dynamics, and future changes. Asia-Pac. J. Atmos. Sci., 50, 69-81, doi:10.1007/s13143-014-0028-3.

_ X. Wang, C. Wang, and B. Dewitte, 2015: On the relationship between the North Pacific climate variability and the central Pacific El Niño. J. Climate, 28, 663-677, doi:10.1175/ JCLI-D-14-00137.1.

Yu, J.-Y., and H.-Y. Kao, 2007: Decadal changes of ENSO persistence barrier in SST and ocean heat content indices: 1958-2001. J. Geophys. Res., 112, D13106, doi:10.1029/2006JD007715.

_, and S. T. Kim, 2011: Relationships between extratropical sea level pressure variations and the central Pacific and eastern Pacific types of ENSO. J. Climate, 24, 708-720, doi:10.1175/2010JCLI3688.1.

_- H.-Y. Kao, and T. Lee, 2010: Subtropics-related interannual sea surface temperature variability in the central equatorial Pacific. J. Climate, 23, 2869-2884, doi:10.1175/2010JCLI3171.1.

_, Y. Zou, S. T. Kim, and T. Lee, 2012: The changing impact of El Niño on US winter temperatures. Geophys. Res. Lett., 39, L15702, doi:10.1029/2012GL052483.

- P.-k. Kao, H. Paek, H.-H. Hsu, C.-w. Hung, M.-M. Lu, and S.-I. An, 2015: Linking emergence of the central Pacific El Niño to the Atlantic multidecadal oscillation. J. Climate, 28, 651-662, doi:10.1175/JCLI-D-14-00347.1.

Zhang, W. J., F.-F. Jin, J. P. Li, and H.-L. Ren, 2011: Contrasting impacts of two-type El Niño over the western North Pacific during boreal autumn. J. Meteor. Soc. Japan, 89, 563-569, doi:10.2151/jmsj.2011-510.

,-- , and A. Turner, 2014: Increasing autumn drought over southern China associated with ENSO regime shift. Geophys. Res. Lett., 41, 4020-4026, doi:10.1002/2014GL060130.

—, Y. Wang, F.-F. Jin, M. F. Stuecker, and A. G. Turner, 2015: Impact of different El Niño types on the El Niño/IOD relationship. Geophys. Res. Lett., 42, 8570-8576, doi:10.1002/ 2015GL065703. 